811.163.41'35

https://doi.org/10.18485/msc.2018.47.3.ch5

\author{
Душка Б. КЛИКОВАЦ \\ Филолошки факултет \\ Универзитета у Београду
}

\title{
О ЗНАКОВИМА У ПРАВОПИСУ (2): РЕЧЕНИЧНИ ЗНАКОВИ
}

\author{
Интерпункција је, у ствари, део синтаксе.
}

(А. Белић)

\begin{abstract}
Рад је посвећен интерпункцијским (= реченичним) правописним знацима. Приказују се и коментаришу њихове дефиниције и инвентар у постојећим српским и хрватским правописима, а предлаже се и дистинкција између правописних знакова у ужем смислу - оних који се пишу као посебни знаци, и правописних знакова у ширем смислу, који се на другачије начине комбинују с текстом - а то су велико слово, тип слова и белине. На крају се разматрају разлози због којих би било оправдано интерпункцијске знаке у правописима издвајати као посебну групу, и даје се пример за то како се интерпункцијом исказ може стилски нијансирати.
\end{abstract}

Кључне речи: српски језик, правопис, правописни знаци, интерпункција, реченични знаци, правописни знаци у ужем смислу, правописни знаци у ширем смислу

\section{1. Увод}

У првом делу овог рада (Кликовац 2017) говорили смо уопште о знаковима који се додају словима (или, ређе, цифрама) да би се добио јасан, прегледан писани текст. Изложили смо инвентаре тих знакова у досадашњим правописима, заједно с њиховом поделом - у правописима који је дају - на оне који се тичу и оне који се не тичу реченице. Предложили смо и терминолошка решења: правописни знаци за све знакове, интерпункиијски или реченични за оне који се тичу реченице, те помоћни правописни или нереченични знакови за оне који се не тичу реченице. У овом, другом делу рада позабавићемо се третманом реченичних знакова у досадашњим правописима - начином на који се дефинишу и њиховим инвентаром, као и питањем има ли потребе издвајати их у правописима као посебну групу. 


\section{2. Дефиниције реченичних знакова}

За дефинисање интерпункције веома је важан однос између говора и писма, будући да интерпункцијски знаци у начелу одговарају неким прозодијским чиниоцима у говору - пре свега паузама и интонацији (што је и основа за усвајање основних правила интерпункције у школи). Међутим, писање најчешће није пуко записивање говора, те су говор и писање два засебна медијума, од којих сваки има своја правила и изражајне могућности. ${ }^{1}$ Према томе, и у дефинисању интерпункције могуће је указати на њихове корелате у говору, али је могуће и не освртати се на њих. Друго: интерпункцијске знакове је могуће дефинисати са гледишта онога који текст пише и онога који текст чита. Кад је реч о читању - може бити у питању читање наглас или читање као разумевање. У дефиницијама налазимо све ове компоненте, у различитим комбинацијама и различито наглашене. Ипак, у готово свим правописима помиње се најважнија улога интерпункције - да разграничава делове текста.

Љ. Стојановић (1891: 25) првенствено истиче да инерпункција служи да разграничи једну реченицу од друге, али истиче и њену улогу као упутства за гласно читање. Ево шта он каже: „Да би се при читању знало које речи припадају којој реченици, и где треба предахнути, а где глас дићи, употребљавају се ови знаци [...]."

У неким правописима интерпункција се дефинише пре свега на основу своје улоге у записивању говора, тј. на основу своје корелације с прозодијом, али се помиње и значењско ,рашчлањавање” текста. Тако Симић и др. (1998: 97) одмах на почетку поглавља о интерпункцији кажу: „Интерпункцијом обележавамо говорне паузе”, а нешто даље: „Интерпункцијом називамо писмено рашчлањавање и уобличавање садржаја говора помоћу интерпункцијских знакова; - говорни израз рашчлањавања и уобличавања - јесу паузе и интонащија" (стр. 99; курзив изворни). У основи је слична и дефиниција коју дају Пижурица и др. (2010: 98): „Да би се говор верно пренео у писани текст, речи се одвајају белинама, а интонација реченице, смисаоно рашчлањавање, паузе међу деловима исказа и др. означавају се правопис ним знацима, ин т ерпункци ј о м."

У неким дефиницијама корелација с говором уопште се не помиње. Правопис 1960 (стр. 91) даје дефиницију из угла оног који текст пише, а интерпункција му служи да обликује његов смисао; тај правопис је, уједно, и једини правопис који не помиње улогу интерпункције да раздељује текст на мање целине: „У писању се, ради јаснијег приказивања онога што хоће да се каже, употребљавају поједини знаци које, узете заједно, зовемо интер-

\footnotetext{
${ }^{1}$ На пример, Клајн (2001: 139) констатује да „[в]елика већина писаних текстова, у наше време, нити настаје бележењем говора, нити је намењена читању наглас”, да „[н]е бележимо говор ради говора, него ради садржаја”, те да је писање „у знатној мери прерасло функцију бележења говора и постало засебан систем, са сопственим средствима и сопственим унутарњим законитостима". И даље: ,'Засебан' овде нипошто не значи 'независан од говора', али је важно уочити да бележење говора није ни примарна ни једина сврха писма.” И Бугарски (1996: 184) истиче да су „govor i pisanje dva ravnopravna i bar delimično nezavisna medijuma jezičke aktivnosti”. Један пример за то даћемо на крају т. 4.8.3, посвећеној белинама у тексту.
} 
пункцијом." Симић и др. 1993 (стр. 130) нуде дефиницију опет засновану на смислу текста, али из угла оног који текст чита и помињући „груписање речи”: „Уз помоћ интерпункције ријечи се у тексту групишу тако да читалац разумије њихов садржај на начин који одговара пишчевим мислима и ставовима о предмету казивања."

М. Дешић у својим школским правописима (1994: 131; 2015: 161; цитат према овом другом) интерпункцијске знакове кратко дефинише на основу њихове основне улоге да сегментују текст - као „правописне знакове којима се при писању раздвајају реченице и њихови делови".

Пешикан и др. (1993: 252) разматрају различите аспекте и улоге интерпункције:

На смисаону рашчлањеност казивања, као и на односе и одлике његових саставница (делова, елемената) указује се правописним знацима или интерпункцијом. ${ }^{2}$ Улога правописних знакова, међутим, није само да надомести оно што се у усменом говору изражава интонацијом и застанцима, него и да допуне и унапреде изражајне могућности и економичност излагања. Захваљујући правописним знаковима и поступцима, писани текст постиже већу јасност и поготово већу сажетост него усмено казивање, будући да знак често замењује реч или групу речи.

Дакле, истиче се да интерпункција „рашчлањује казивање”, али и да указује и на односе међу тим деловима и на одлике тих делова. Такође се примећује и да она, иако начелно одговара паузама и интонацији у говору, има у писаном тексту и допринос независан од њих.

Бабић и др. ('2002 [1996]: 86) такође истичу улогу интерпункције да „раставља текст на делове”, као и корелацију између ње и прозодије - али наглашавајући првенство писаног текста у односу на говор - а помињу и њену улогу у (гласном) читању:

Razgodci su oni znakovi u pisanome jeziku koji služe za rastavljanje teksta na rečenice i njezine dijelove. [...]

Za misaono oblikovanje govora, za rastavljanje većih ili manjih govornih cjelina u govoru služe kraće ili dulje stanke, intonacija, jačina i rečenični tempo, a u pismu se to označuje razgodcima. Zbog različitosti naravi govorenoga i pisanoga jezika razgodci ne mogu u potpunosti biti jednakovrijednice govornim vrjednotama. [...] Njihov je zadatak prvenstveno u tome da se zna kako napisano valja razumjeti, a onda i pročitati, a u drugome je planu kako govoreno valja zapisati. Govoreno se može zapisati na više različitih načina, a da bude pravopisno dobro zapisano.

Наведене дефиниције своде се на следеће (и најближе ономе што формулишу Пешикан и др. (1993): интерпункцијом се смисао текста обликује, тако што се текст „рашчлањује”, „раставља”, „раздваја” на мање делове и указује на одлике тих делова, односно на односе међу њима; она, приликом записивања говора или гласног читања, одговара елементима прозодије - нарочито паузама и интонацији - али писаном тексту даје и допринос независан од говора.

\footnotetext{
${ }^{2}$ Ова дефиниција, како смо на то скренули пажњу и у првом делу овог рада (Кликовац 2017) не одговара свим знаковима који се употребљавају у правопису, него само реченичним знацима, дакле ономе што се и иначе традиционално назива интерпункцијом.
} 


\section{3. Знакови који се обично сматрају (и) реченичнима}

Неке правописне знаке сви аутори који разликују реченичне и нереченичне знакове, или бар већина њих, сматрају реченичнима. Приказаћемо их табелом, заједно са свим терминима којима се означавају; а да би подаци о терминологији били потпуни, додаћемо и термине из оних правописа одн. радова у којима се правописни знаци не распоређују у групу реченичних одн. нереченичних. Како ће се у табели видети, у неким правописима дозвољавају се и два или више термина за исти знак.

\begin{tabular}{|c|c|}
\hline Знак & Правопис у којем се помиње и термини којима се назива \\
\hline . & $\begin{array}{l}\text { тачка (Стојановић 1891, Новаковић 1894, Петровић 1912, Петровић 1914, } \\
\text { Белић 1923, Белић 1934, Белић 1950, Ново правописно упутство [1943], } \\
\text { Правопис 1960, Пешикан и др. 1993, Дешић 1994, Симић и др. 1993, Си- } \\
\text { мић и др. 1998, Шипка 2000, Пижурица и др. 2010, Дешић 2015), } \\
\text { точка (Броз 1892, Боранић 1951, Бабић и др. }{ }^{6} 2002 \text { [1996], Анић/Си- } \\
\text { лић 2001, Хрватски правопис 2013) }\end{array}$ \\
\hline$?$ & $\begin{array}{l}\text { знак питава (Стојановић 1891, Новаковић 1894, Петровић } 1912, \\
\text { Петровић 1914, Белић 1923, Броз 1892), } \\
\text { упитник (Белић 1934, Белић 1950, Ново правописно упутство [1943], } \\
\text { Правопис 1960, Пешикан и др. 1993, Дешић 1994, Симић и др. 1993, } \\
\text { Симић и др. 1998, Шипка 2000, Пижурица и др. 2010, Дешић 2015, } \\
\text { Боранић 1951, Бабић и др. }{ }^{2} 2002 \text { [1996], Анић/Силић 2001, Хрватски } \\
\text { правопис 2013) }\end{array}$ \\
\hline ! & $\begin{array}{l}\text { знак чуђења (Стојановић 1891), } \\
\text { знак узвикиваша (Броз 1892), } \\
\text { знак узвика (Новаковић 1894, Белић 1923), } \\
\text { узвичник (Белић 1934, Белић 1950, Боранић 1951, Ново правописно } \\
\text { упутство [1943], Правопис 1960, Пешикан и др. 1993, Дешић 1994, } \\
\text { Симић и др. 1993, Симић и др. 1998, Шипка 2000, Пижурица и др. } \\
\text { 2010, Дешић 2015), } \\
\text { знак усклика (Петровић 1912, Петровић 1914), } \\
\text { ускличник (Бабић и др. '2002 [1996], Анић/Силић 2001, Хрватски } \\
\text { правопис 2013) }\end{array}$ \\
\hline , & $\begin{array}{l}\text { запета (Стојановић 1891, Новаковић 1894, Петровић 1912, Петровић } \\
\text { 1914, Белић 1923, Правописно упутство [1929], Белић 1934, Белић } \\
\text { 1950, Ново правописно упутство [1943], Пешикан и др. 1993, Дешић } \\
\text { 1994, Симић и др. 1998, Шипка 2000, Пижурица и др. 2010, Дешић } \\
\text { 2015), } \\
\text { зарез (Броз 1892, Боранић 1951, Бабић и др. }{ }^{6} 2002 \text { [1996], Анић/Си- } \\
\text { лић 2001, Хрватски правопис 2013, Правописно упутство [1929], } \\
\text { Белић 1934, Правопис 1960, Пешикан и др. } 1993^{3} \text {, Симић и др. 1993, } \\
\text { Симић и др. 1998) }\end{array}$ \\
\hline
\end{tabular}

${ }^{3}$ У поднаслову одељка посвећеном овом знаку стоји запета (зарез), али се у каснијем тексту јавља само зарез; аутори и кажу да ће се више служити овим другим, „због поколења која су се школовала после 1960. и од којих ће реално зависити будући доминантни изражајни обичаји“, те да „треба знати и уважавати и један и други термин“ (Пешикан и др. 1993: 253). Пижурица и др. (2010) од термина зарез одустају. 
456

\begin{tabular}{|c|c|}
\hline- & $\begin{array}{l}\text { цртица (Стојановић 1891, Броз 1892, Бабић и др. }{ }^{6} 2002 \text { [1996], } \\
\text { Хрватски правопис 2013), } \\
\text { пауза (Стојановић 1891), } \\
\text { станка (Боранић 1951), } \\
\text { знак почивке (Новаковић 1894, Петровић 1912, Петровић } 1914, \\
\text { Белић 1923, Белић 1950), } \\
\text { знак прекида (Новаковић 1894, Петровић 1912, Белић 1923), } \\
\text { прекидни знак (Белић 1934, Белић 1950, Ново правописно упутс- } \\
\text { тво [1943]), } \\
\text { црта (Белић 1923, Белић 1934, Белић 1950, Ново правописно } \\
\text { упутство [1943], Правопис 1960, Пешикан и др. 1993, Дешић } \\
1994, \text { Симић и др. 1993, Симић и др. 1998, Шипка 2000, Пижури- } \\
\text { ца и др. } 2010, \text { Дешић 2015, Анић/Силић 2001) }\end{array}$ \\
\hline ; & $\begin{array}{l}\text { тачка и запета (Стојановић 1891, Новаковић 1894, Петровић } \\
\text { 1912, Петровић 1914, Белић 1923, Белић 1934, Белић 1950, Ново } \\
\text { правописно упутство [1943]), Пешикан и др. 1993, Дешић 1994, } \\
\text { Симић и др. 1998), } \\
\text { мачка и зарез (Правопис 1960, Пешикан и др. 1993, Симић и др. 1993), } \\
\text { мачка са зарезом (Пешикан и др. 1993), } \\
\text { тачка са запетом (Шипка 2000, Пижурица и др. 2010, Дешић 2015), } \\
\text { мочка са зарезом (Броз 1892, Бабић и др. }{ }^{5} 2002 \text { [1996], Хрватски } \\
\text { правопис 2013) } \\
\text { мочка и зарез (Боранић 1951), } \\
\text { точка-зарез (Анић/Силић 2001) }\end{array}$ \\
\hline : & $\begin{array}{l}\text { две тачке (Стојановић 1891, Новаковић 1894, Петровић } 1912, \\
\text { Петровић 1914, Белић 1923, Белић 1934, Белић 1950, Ново право- } \\
\text { писно упутство [1943], Правопис 1960, Дешић 1994, Пешикан и } \\
\text { др. } 1993, \text { Симић и др. 1998, Пижурица и др. 2010, Дешић 2015), } \\
\text { двије тачке (Симић и др. 1993), } \\
\text { двије точке (Броз 1892, Боранић 1951), } \\
\text { двотачка (Пешикан и др. 1993, Симић и др. 1993, Симић и др. } \\
\text { 1998, Шипка 2000), } \\
\text { двоточка (Анић и Силић } 2001, \text { Хрватски правопис 2013), } \\
\text { двоточје (Бабић и др. }{ }^{6} 2002 \text { [1996], Анић/Силић 2001) }\end{array}$ \\
\hline
\end{tabular}

${ }^{4}$ Код Новаковића и Петровића (1912) термин знак прекида означава два знака - црту и тротачку.

${ }^{5}$ Једанпут се, приликом набрајања интерпункцијских знакова, помиње и термин тачка-запета, као равноправан с термином тачка са запетом (стр. 98), али се касније употребљава само овај други термин.

${ }^{6}$ Нешто опширније о терминологији у вези с двотачком в. Кликовац 2014. 


\begin{tabular}{|c|c|}
\hline $\begin{array}{c}\text { "” или „," } \\
\text { или » «"7 }\end{array}$ & $\begin{array}{l}\text { знак навођена (Стојановић 1891, Новаковић } 1894^{8} \text {, Броз } 1892, \\
\text { Петровић 1912, Петровић 1914), } \\
\text { наводни знак (Белић 1923), } \\
\text { наводници (Белић 1934, Белић 1950, Ново правописно упутство } \\
\text { [1943], Боранић 1951, Правопис 1960, Пешикан и др. 1993, Дешић } \\
\text { 1994, Симић и др. 1993, Симић и др. 1998, Шипка 2000, Пижури- } \\
\text { ца и др. 2010, Дешић 2015, Бабић и др. }{ }^{6} 2002 \text { [1996], Анић/Силић } \\
\text { 2001, Хрватски правопис 2013) }\end{array}$ \\
\hline , , & $\begin{array}{l}\text { полунаводници (Правопис 1960, Пешикан и др. 1993, Симић и др. } \\
\text { 1993, Симић и др. 1998, Дешић 1994, Шипка 2000, Пижурица и } \\
\text { др. 2010, Бабић и др. }{ }^{2} 2002 \text { [1996], Анић/Силић 2001) }\end{array}$ \\
\hline $\begin{array}{c}\text { ( ) или [ ] } \\
\text { и др. }\end{array}$ & $\begin{array}{l}\text { знак заграде (Стојановић 1891, Новаковић 1894, Петровић 1912), } \\
\text { заграда (Петровић 1914, Белић 1923, Белић 1934, Белић 1950, Ново } \\
\text { правописно упутство [1943], Правопис 1960, Пешикан и др. 1993, } \\
\text { Дешић 1994, Симић и др. 1993, Симић и др. 1998, Шипка 2000, } \\
\text { Пижурица и др. 2010, Дешић 2015, Броз 1892, Боранић 1951), } \\
\text { заграде (Бабић и др. } 62002 \text { [1996], Анић/Силић 2001, Хрватски } \\
\text { правопис 2013) }\end{array}$ \\
\hline
\end{tabular}

У вези са заградом треба напоменути да је старији правописи понекад третирају као нереченични знак. Тако Броз (1892) заграду разматра само унутар речи: „Zagrada ( ) se upotrebljava pokazujući, da se ono u riječi, što je zagrađeno, može po volji i izostaviti; n. p. riječ iguman glasi u genetivu jednine igum(a)na.., koje znači, da se igum(a)na može čitati i igumana i igumna" (Броз 1892: 50). Друге употребе заграде не помиње. Слично томе, Белић заграду (облу и угласту) разматра не у оквиру поглавља „Интерпункција”, него под насловом „О осталим знацима” (Белић 1923) одн. „Други знаци” (Белић $1934,1950)$, заједно са акценатским знацима, апострофом, цртицом и другим нереченичним знацима.

Преостао нам је знак који данас (али у српској средини тек од 1993!) има облик трију тачака поређаних водоравно а обично се назива три тачке. Ево термина којима се он означава(о):

\footnotetext{
${ }^{7}$ Графичко решење овог знака је посебно питање, којим се овде нећемо бавити. Пижурица и др. (2010) - први и без икаквог објашњења - дају само решење „”, иако су друга два традиционално чешћи и у пракси устаљени; тако чини и Дешић 2015. Бабић и др. прописују два облика: „” и » «.

${ }^{8}$ Под термином знак навођењ $а$ Новаковић наводи три знака: „“, ,' и - (стр. 358).
} 


\begin{tabular}{|c|c|}
\hline .... или ... & $\begin{array}{l}\text { неколико тачака (Стојановић 1891, Белић 1923, Белић 1934, Бе- } \\
\text { лић 1950, Правопис 1960), } \\
\text { знак прекида (Новаковић 1894, Петровић 1912, Петровић 1914, }{ }^{10} \\
\text { Пешикан и др. 1993, Пижурица и др. 2010), } \\
\text { „тачкице” (Белић 1923, Белић 1934, Белић 1950), } \\
\text { неколике тачке (Ново правописно упутство [1943]), } \\
\text { више тачака (Белић 1950) }{ }^{11}, \\
\text { три тачке (Пешикан и др. 1993, Симић и др. 1993, Дешић 1994, } \\
\text { Шипка } 2000, \text { Пижурица и др. 2010, Дешић 2015), } \\
\text { тротачка (Симић и др. 1993), } \\
\text { виче точака (Броз } 1892^{12}, \text { Боранић }{ }^{10} 1951 \text { [1921]) } \\
\left.\text { три точке (Боранић }{ }^{10} 1951 \text { [1921] }\right)^{13} \\
\text { троточка (Анић/Силић } 2001, \text { Хрватски правопис 2013) } \\
\text { троточје (Бабић и др. }{ }^{6} 2002 \text { [1996], Анић/Силић 2001) }\end{array}$ \\
\hline
\end{tabular}

Видели смо (Кликовац 2012) да је он у досадашњим правописима имао различит третман, при чему се обично подразумевало да је мање важан (нпр. Белић га у сва четири издања свог правописа о њему говори у оквиру црте, а у издању из 1950. и у оквиру тачке). Новаковић (1894), Броз (1892) и Бабић и др. ${ }^{6} 2002$ [1996] тај знак сматрају реченичним. Боранић (1951) га такође сврстава (и) у реченичне. У Правопису 1960 он се помиње и у групи реченичних и у групи нереченичних, али разматра у оквиру ових других. У правописима Пешикана и др. (1993) и Пижурице и др. (2010) није јасно да ли се сматра реченичним или не (јер је обрађен под општим насловом „Остали правописни и помоћни знакови”). ${ }^{14}$ Слично томе, Дешић $(1994,2015)$ о њему говори под насловом „Остали правописи знаци”, заједно с цртицом, апострофом, косом цртом, знаковима за акценте и др. нереченичним знаковима. Симић га у свом правопису из 1993. (Симић и др. 1993) сврстава у интерпункцијске знакове - али пошто у њих сврстава и апостроф и генитивни знак, који су нереченични знаци, није сигурно у какве знакове убраја тротачку. У правопису из 1998. (Симић и др. 1998: 120) тротачку убраја у знакове који су увек нереченични. Најзад, код Анића и Силића (2001) такође није јасно да ли је тротачка реченични или нереченични знак.

${ }^{9}$ Овај знак тим термином Белић означава у свим издањима свог правописа кад о њему говори у оквиру „знака почивке” [= црте].

${ }^{10}$ И Новаковић и Петровић термином знак прекида обележавају два знака - три тачке и црту.

${ }^{11}$ Овај термин Белић употребљава у издању правописа из 1950, говорећи о овом знаку на крају свог излагања о тачки.

${ }^{12}$ И Броз и Боранић овај знак називају и само точке.

${ }^{13}$ Боранић, заправо, има назив више точака (обично три), а осим три точке, и три точке (или виме њих).

${ }^{14}$ Следећи цитат из правописа Пешикана и др. (1993) могао би лако да значи да ти аутори три тачке не сматрају реченичним знаком: „Без зареза и тачке није могућно исправно писање ни најједноставнијих текстова, а многе реченице својим карактером и склопом изискују и друге реченичне знакове: црту, тачку са зарезом, наводнике, двотачку (или две тачке), заграду, у питник и (знатно ређе) уз в и чн ик” (стр. 253; спационирани слог изворни). Друга могућност је да су тај знак као реченични превидели, као мање важан. - У правопису Пижурице и др. (2010) тог текста нема. 
Међутим, с обзиром на то да овај знак може означавати крај реченице на исти начин на који то могу и тачка, упитник и узвичник, он је несумњиво (и) интерпункцијски (в. опширније у Кликовац 2012). ${ }^{15}$

\section{4. Знаци које се сматрају реченичним само у неким правописима}

\section{1. Црте}

Анић и Силић (2001) у „правописне знакове у ужем смислу” (=интерпункцијске) убрајају и цртее. Тај знак дефинишу овако (стр. 79):

Crte kao pravopisni znak u užem smislu odjeljuju dio koji s rečenicom u koju je uključen nije organski, tj. značenjski i gramatički, povezan. U toj ulozi zamjenjuju dvostruki zarez ili zagrade. U usporedbi sa zarezom i zagradama one su jače, izražajnije: Zbog nervoze taj neuropat nije plastičan, crtajući - kako to dobro opaža g. Marjanović - uvijek samo gibanje i pokret, nikada mir pravog plastika.

Наш коментар био би следећи. Ако бисмо две црте сматрали посебним интерпункцијским знаком због њихове посебне улоге, онда бисмо из истог разлога посебним знаком морали сматрати и два зареза који су употребљени у истој таквој улози. Међутим, сами ови аутори, говорећи о тако употребљеном зарезу, кажу (стр. 23):

Umetnuti nezavisni dijelovi odvajaju se zarezom. To su oni dijelovi koji nisu u izravnoj značenjskoj vezi s rečenicom u koju su umetnuti[.]

Дакле, иако могу имати исту функцију - да издвоје део реченице - црта и зарез се у том правопису не третирају једнако: две црте се сматрају посебним знаком, а два зареза не. Тад се, наравно, поставља питање зашто је двема цртама дат посебан статус.

Начелно, овде се поставља питање да ли је употреба (удвојене) црте да издвоји један део реченице хомонимична са оним њеним употребама у којима она одваја један део реченице (одн. текста). Рекли бисмо да је ту у питању не хомонимија, него полисемија, одн. полифункционалност интерпункцијског знака: и кад се употребљава удвојено и кад се употребљава само једном, црта означава паузу, а и у удвојеној употреби и бар једној њеној једнострукој употреби та пауза служи истицању. Стога би се и њена удвојена употреба могла посматрати као један члан у оквиру категорије свих употреба црте, при чему та категорија има своју унутрашњу структуру (тј. није класична - дефинисана помоћу неопходног и довољног услова).

\footnotetext{
${ }^{15}$ Од тих знакова разликује се по томе што реченица чији крај обележава може бити и довршена и недовршена, затим по томе што може стајати и на крају реченице и унутар ње (после чега њен наставак следи) и, најзад, што може раздвајати и делове текста (слично црти).
} 


\section{2. Комбинације упитника и узвичника}

У оквиру „правописних термина” које предлаже, М. Шипка (2000: 1417), осим узвичника и упитника наводи и упитник с узвичником. А Хрватски правопис 2013 осим упитника и ускличника говори и о упитнику с ускличником и ускличнику с упитником. Први знак се пише „,na kraju rečenice kojom se izražava istodobno pitanje i čuđenje, ushit ili oduševljenje”, а други „na kraju rečenice kojom se izražava istodobno čuđenje, ushit ili oduševljenje i pitanje". Такође, ти знакови могу бити употребљени и без текста; први тада означава „upitnu šutnju s čuđenjem, ushitom ili oduševljenjem”, а други „с̌uđenje, ushit ili oduševljenje s pitnom šutnjom" (сви цитати на стр. 90). Дакле, код првог знака у првом плану је питање, а код другог је оно мање изразито него друге поменуте емоције.

Као коментар, констатоваћемо најпре да се комбинацијом упитника и узвичника не ствара квалитативно ново значење, него се она своди на збир својих компоненти - упитности и узвичности (при чему, очигледно, преовлађује она компонента коју изражава први знак од тих двају).

Друго: упитник и узвичник се могу и понављати - сами или у комбинацији. Ево, рецимо, неколико примера из једног романа (Ana Đokić Pongrašić, Zoe, devojčica sa vrha solitera, Beograd: Laguna, 2003); релевантне знакове смо подвукли:

(1) - Zoe? Zoe? Hm, Zoe - i ništa mu nije bilo jasno.

A onda mu je sinulo. U drugom trenutku. Kao i obično.

- ZOE!!! - viknuo je tako da su ga čule sve komšije, tamo dole čak do dvadeset trećeg sprata. (стр. 16)

(2) Odbrojava sekunde.

Tri!

Dva!!

Jedan!!! (стр. 18)

(3) U istom času pred sobom je ugledala dobro poznato, najpoznatije lice.

- Tata?!! (стр. 114)

Дакле, комбинација ових двају знакова има много више него што су две које се помињу у правописима (Анић/Силић (2001: 56) бележе чак и комбинацију „?!?!”). А свима њима дати статус посебних знакова - нити је ко предложио, нити би, верујемо, то учинио. Стога не изгледа оправдано такав статус давати ни комбинацијама „,?!” и „!?”.

\section{3. Апостроф и тзв. , генитивни знак”}

У двама старијим изворима - код Љ. Стојановића (1891) и у Новом правописном упутству [1943] - међу интерпункцијским знаковима помиње се и апостроф. Рекли бисмо да је такав поступак пре резултат потребе да се апостроф помене (јер се у оба та правописа о нереченичним знаковима уопште и не говори) него његовог промишљеног сврставања у реченичне знакове: тај знак се јасно везује за појединачне речи. 
Исто важи и за један новији правопис - Симић и др. 1993, у којем се у интерпункцију сврстава не само апостроф него и „тзв. 'генитивни знак””; да је у питању грешка, сугерише и то што исти аутор у другом правопису (Симић и др. 1998), као и у његовој, бар што се правописних знакова тиче, практично прештампаној верзији (Симић 2003) те знаке сврстава међу знакове који су увек нереченични.

\section{4. Цртица (,, spojnica”)}

Бабић и др. ('2002 [1996]: 114-115) сматрају да се цртица (њихов термин je спојница) може употребљавати и као интерпункцијски знак (,razgodak”):

Spojnica je svojom glavninom pravopisni znak, a kao razgodak u pisanju polusloženica [...] i u pisanju riječi koje se u rečenici ne izgovaraju kao cjelina, nego u svojim dijelovima: radi jačega naglašavanja tih dijelova, rečeničnoga naglaska ili kojega drugoga stilskoga učinka:

A onda: Kaj-bum-ščak!

... a neko drekne iz dvorišta u debelom basu:

- Za-po-ve-da-ju-

- pituljicu si opet smazao - vikala je debeljuskasta, jedra kuharica - kud čas prije.

- Ni-i-i-sa-am

Најпре, не видимо како би цртица у писању полусложеница могла бити реченични знак: помоћу ње се у том случају спајају две речи тако да чине целину која функционише као јединствена реч. Друго: у речима које се изговарају „u svojim dijelovima” цртица опет означава поделу речи на делове (пре свега слогове - како видимо из примера); и ако се та реч осамостали у посебну реченицу, цртица задржава ту своју основну употребу. Другим речима, не видимо да је оправдано посматрати је у том случају као реченични знак.

\section{5. „Двострука иртища”}

Анић и Силић (2001) на два места у свом правопису у „правописне знакове у ужем смислу” (=интерпункцијске) убрајају и „двоструку цртицу” (која није знак једнакости); једанпут то чине у уводном делу, кад набрајају знакове који би могли бити и реченични и нереченични (стр. 7), и други пут под насловом „Dvostruka crtica”, где кажу (стр. 82): „Dvostruka crtica kao pravopisni znak u užem smislu pokazuje, kao i crtica, da njome rastavljeni elementi čine posebnu jedinicu (cjelinu).” „Цртицу” пак ови аутори дефинишу као „,pravopisni znak koji pokazuje da elementi rastavljeni njime tvore usku cjelinu i zajedno predstavljaju jedinicu na razini riječi” - као у примерима $\phi u$ зиолошко-психолошки, 5-дневни, Андрија Качић-Миошић, ку-ћи-ияа итд. Јасно je, дакле, реч о знаку који се везује за речи (како и сами аутори кажу), па није јасно зашто би „двострука цртица” спадала у интерпункцијске знакове. Биће, дакле, да је у питању грешка. 


\subsection{Koca upma}

Бабић и др. ( ${ }^{6} 2002$ [1996]: 122) помињу и да се коса црта (њихов термин је коса иртица) може употребити као интерпункцијски знак („razgodak”) „da se označi kraj stiha kad se stihovi prenose u vodoravnome slijedu radi uštede u prostoru". Такву употребу црте бележе и други правописи (нпр. Пижурица и др. 2010, који наводе пример Пучина плава / спава. / Прохладни пада мрак. / Врх хриди ирне / трне / задњи румени зрак), али се само у овом правопису она сматра интерпункцијском. Међутим, нама се чини да би она у таквој употреби пре била текстуални знак, будући да се подела песме на стихове тиче текста, а не реченице (како се добро види и у датом примеру).

\section{7. Више/низ тачака}

Бабић и др. ('2002 [1996]: 110-111) овај знак, који називају вишеточје, дефинишу као „razgodak kojim se označuje dulja stanka ili se posebno ističe da je izostavljen dulji tekst”. Графички, он се састоји „od pet, šest ili više točaka, pa i cijeloga rijetka, a iznimno i nekoliko redaka”, а њиме ce „valja služiti samo kad to traže stilski razlozi".

Симић и др. 1993 (на стр. 131) и Симић и др. 1998 (стр. 121) помињу низ тачака, којим „назначујемо изостављени одломак већег обима”; у првом правопису тај се знак помиње у оквиру интерпункције, а у другом у оквиру оних знакова који су само нереченични.

Шипка (2000: 1417) помиње и термин више тачака, који означава знак „,...., али не говори ништа о томе како се тај знак употребљава нити да ли је број тачака прописан (а не помиње ни то да ли би се тај знак убрајао у реченичне или нереченичне).

Можемо рећи да би, с обзиром на то да означава изостављање текста већег од реченице, знак више/низ тачака био, заправо, текстуални, а не интерпункцијски.

\section{8. Велико слово, типови слова, белине}

4.8.1. Велико слово. У поглављу „Razgodci” Бабић и др. '2002 [1996] (стр. 87) кажу и следеће: „Za oznaku početka rečenice služi i veliko slovo, ali se o tome govori u poglavlju Velika i mala slova.” Дакле, ови аутори и велико слово сматрају интерпункцијским знаком - који се, међутим, у правопису разматра одвојено од других интерпункцијских знакова. Анић и Силић (2001: 92) велико слово такође експлицитно називају „правописним знаком”.

И заиста, велико слово које се пише на почетку реченице има исту улогу као и интерпункцијски знак на крају реченице - а то је да одвоји једну реченицу од друге. ${ }^{16}$ У том смислу би се оно могло (а вероватно и морало) сматрати интерпункцијским знаком.

${ }^{16}$ Клајн (2000: 152, фн.) примећује: „Теоријски би се велико слово на почетку реченице могло сматрати редундатним, пошто и тачка обележава границу међу реченицама; али тачка је не- 
Велико слово на почетку реченице је теоријски занимљиво утолико што нема пандан у говору ${ }^{17}$ - што је чињеница коју обични корисници језика најчешће нису свесни.

4.8.2. Типови слова. У правопису Бабића и др. као интерпункцијски знаци помињу се и „ројеdini tipovi slova”, који служе „,za isticanje pojedinih rečenica i rečeničnih dijelova” (стр. 87), одн. ,za različite sintaktičke potrebe, za označivanje rečeničnoga naglaska ili isticanja pojedinih dijelova, a katkata i cijele rečenice” (стр. 122). У питању су „razmaknuta slova”, „kosa slova” и „velika slova” (ова последња се употребљавају „iznimno”, „za isticanje kojega rečeničnoga dijela ili cijele rečenice" (стр. 123)).

И Дешић (2015: 193) типове слова сматра правописним знацима:

Типови слова су у ствари правописни знаци. Речи, групе речи и реченице пишу се обичним слогом, али при истицању употребљавају се курзив (коса слова, италик), црна слова (болд) и размакнута слова (спационирана).

А Симић и др. (1998: 122) у оквиру знакова који су само нереченични помињу и линију за подвлачење - која, заправо, има исту улогу као и другачији тип слога од обичног:

Подвлачењем се може истаћи део текста [...]. Постоје равна и валовита, једнострука и двострука, танка и пуна, континуирана и испрекидана линија - за евентуално нијансирање сврхе подвлачења.

Сагласили бисмо се с тим да је и тип слова некакав знак - који говори да је одређени део реченице и текста на неки начин наглашен. У том смислу било би оправдано сврстати га у правописне знаке - тим пре што се тип слова који служи наглашавању (курзив, полумасни слог) могу заменити и подвлачењем, дакле знаком који се дописује тексту. Што се тиче његовог домета, тип слова би могао бити и реченични знак и текстуални знак.

4.8.3. Белине. Хрватски правопис 2013 у правописне знаке - истог реда као што су точка, упитни, ускличник и др. - убраја и бјелину - „празно мјесто у тексту" (стр. 83).

Дешић (2015: 193) такође убраја у правописне знаке и белине, али под њима не подразумева само празно место између два знака:

Систем белина такође припада правопису. ${ }^{18}$ То је размак између речи, редова, пасуса, поглавља. Он је у најужој вези са састављеним и растављеним писањем речи [...]. У ствари, систем белина односи се на цео простор који заузима један текст, на обликовање

довољно упадљива да би сама успешно обавила тај задатак, што је и био историјски разлог да се (не само у нашем језику) уведе ова употреба великог слова."

${ }^{17}$ На пример, Р. Бугарски (1996: 190-191) у систему писања разликује две ,relativno distinktne kategorije jеzičkih ројаva”, од којих је једна „direktno preuzeta iz govora i samo prilagođena medijumu pisanja”, а друга проистекла непосредно из писања и „с̌еsto nema nikakvih ekvivalenata u govoru”. Бугарски интерпункцију сматра „prelaznim oblikom” између те две категорије, будући да она не може да пренесе сва значења која има интонација у говору, а у другу категорију смешта, између осталог, одвојено писање речи и употребу великих слова, „,kojoj u govoru ništa ne odgovara”.

${ }^{18}$ И, на стр. 194: „Има још правописних знакова, као и посебних: звездица, ситне бројке, знак степена, знак једнакости, тилда, знаци порекла, типови слова, систем белина, специјални симболи" (курзив наш - Д.К.). 
ступца и пасуса: штампање десне ивице ступца (редови једнаки по дужини) и увлачење реда на почетку пасуса.

Из цитата бисмо закључили да су белине знак који може бити и реченични (јер одвајају реченице), али и неречични - јер раздвајају и речи и делове текста.

Питање белина је такође теоријски веома занимљиво, јер указује на то да су говор и писање заиста два оделита система комуникације, од којих сваки има своја правила. Наиме, белине се могу сматрати нултим знаком (тј. одсуством знака) у писању; међутим, оне не одговарају нултом знаку у говору: нулти знак у говору су паузе, а њима у писању одговарају писани знакови - интерпункција.

4.8.4. Напоменимо, на крају, да о великом слову на почетку реченице и белинама говоре и Пешикан и др. (1993: 252), али не као о правописним знацима, него као о нечему са чиме се правописни знаци „допуњавају”:

У својој служби правописни знакови се допуњавају с великим словом на почетку реченице и с белинама између речи и знакова. У сложенијем и опширнијем тексту допуњава се правописни поступак рашчлањавањем на ставове (ставке, пасусе, тј. прелажењем на нови ред, обично увучени), као и разбрајањем делова (нумерацијом или алфабетским обележавањем), а такође подбелешкама (фуснотама, напоменама испод текста). - У поезији се преласком на нови ред и повећаном међуредном белином текст дели на стихове и строфе.

То је, свакако, други могући поступак: да се правописним знацима сматрају само они који се пишу као посебни знаци, који се, дакле, речима, реченицама и тексту дописуjу, или у њих уписуjу, а да се све остало - одсуство писања (белине) и начин на који се слова пишу (велико слово, типови слова) - сматрају нечим што се с тим знацима комбинује, допуњава. А ако смо склони томе да и ове друге сматрамо ипак правописним знацима, онда би они свакако заслуживали посебан статус. Термин којим би се они могли означити јесте правописни знации у ширем смислу - за разлику од типичних правописних знакова - оних који се пишу као посебни знаци и које бисмо могли назвати правописним знацима у ужем смислу.

\section{5. О потреби издвајања реченичних знакова из правописних знакова уопште}

У првом делу овог рада (Кликовац 2017) видели смо да се реченични знаци не издвајају у свим правописима као посебна група. Иако се то традиционално чинило и у српској и у хрватској средини, у новијим правописима то није увек случај (в. Дешић 1994; Дешић 2015, Пешикан и др. 1993 и Хрватски правопис 2013). Разлог је вероватно практичне природе: корисника правописа можда не би требало оптерећивати тиме да ли је нека употреба правописног знака интерпункцијска или не, јер он само жели да зна у којим све случајевима тај знак треба употребити. 
Иако то начелно може бити тачно, сматрамо да има разлога интерпункцијске знакове посматрати у правописима као издвојену групу. ${ }^{19}$ Прво, они, бар начелно, одговарају елементима прозодије. Друго, без неких од њих не може се написати ни најједноставнија реченица. ${ }^{20}$ Треће, њихово усвајање у вези је са усвајањем одређених синтаксичких знања. И четврто, интерпункцијом је могуће нијансирати исказ на различите начине. Ништа од тога не важи за помоћне правописне знаке. ${ }^{21}$

Последње наведено својство интерпункције илустроваћемо једним примером. Пролог Травничке хронике Иве Андрића садржи и следећи део (у питању је монолог Сулејман-бега Ајваза, који препричава свој разговор с једним Сплићанином):22

- Па ето како. Лијепо ме човјек пита: „Спремате ли се мусафирима у Травнику?” „Јок ми”, кажем ја, „није нам до мусафира.” „Е, било вам не било, ваља да им се спремате”, каже, ,jер ће вам стићи француски конзул. Тражио Бунапарта на Капији у Стамболу да може послати свога конзула, да отвори конзулат у Травнику и да ту сједи. И већ му је то одобрено. Још ове зиме се можете надати конзулу.” Одбијам ја на шалу: „Стотине година смо живили без тих конзула па можемо и одсада, а и шта ће конзул у Травнику?” Али он једно те једно. „Како сте живили да сте живили, сад вам ваља живити са конзулом. Така времена дошла. А конзул ће себи наћи посла; сјешће поред везира да наређује и распоређује, да гледа како се владају бегови и аге а како раја, и да све јавља Бунапарти.” „То нит је било нити може бити”, сузбијам ја влаха, „нико нама никад није у наше послове завиривао, па неће ни тај.” „Е, богами, ви гледајте како ћете”, каже мени он, „али конзула ће вам ваљати примити, јер што Бунапарта затражи нико досад није одбио па неће ни девлет у Стамболу. [...]”

Тај монолог је пренесен као изразито разговоран, неформалан, народски - a то је постигнуто и једноставном и сразмерно оскудном интерпункцијом. Да је она нешто другачија и детаљнија, логички односи у тексту били би наглашенији, због чега би монолог деловао интелектуалније, а могао би се имитирати и спорији, изражајнији, сугестивнији изговор (што, очигледно, Андрићу није био циљ). Ево једне (не, наравно, и једине) такве варијанте (додате или измењене знаке смо подвукли):

- Па ето како. Лијепо ме човјек пита: „Спремате ли се мусафирима у Травнику?” „Јок ми”, кажем ја, „није нам до мусафира.” „Е, било вам_-не било, ваља да им се спремате”, каже, ,jер ће вам стићи француски конзул. Тражио Бунапарта на Капији у Стамболу да може послати свога конзула, да отвори конзулат у Травнику и да ту сједи. И већ му је то

${ }^{19}$ Што се тиче практичног поступка којим ће се у правописима обрађивати интерпункцијски и помоћни правописни знаци, Шипка (2000: 1416) наводи два: да се реченични и нереченични знакови обраде посебно, у различитим поглављима, или да се обе групе сврстају у исто поглавље, али да се у обради сваког од њих издвоје његове реченичне и нереченичне употребе. Из приказа правописа̂ у првом делу овог рада (Кликовац 2017) види се да први поступак примењују - да поменемо само сразмерно новије правописе, и то оне у којима се доследно разликују реченични и нереченични знаци одн. употребе - Правопис 1960, Симић и др. (1998), Бабић и др. ${ }^{6} 2002$ [1996], а други Анић и Силић (2001) и, делимично, Пижурица и др. (2010).

${ }^{20}$ В. и почетак цитата из правописа Пешикана и др. (1993) у фн. 14 у овом раду. - Од помоћних правописних знакова ширу употребу има само цртица, захваљујући својој улози у раздвајању речи на крају реда.

${ }^{21}$ Томе свакако треба додати и чињеницу да је појам интерпункције (као реченичних знакова) давно установљен и у пракси (школској и другој) дубоко утврђен и широко коришћен.

${ }^{22}$ Цитат је узет из књ. друге Сабраних дела, Београд, 1967, стр. 10. 
одобрено. Још ове зиме се можете надати конзулу.” Одбијам ја на шалу: „Стотине година смо живили без тих конзула, па можемо и одсада; а и шта ће конзул у Травнику?” Али он једно те једно. „Како сте живили_да сте живили, сад вам ваља живити са конзулом. Така времена дошла. А конзул ће себи наћи посла: сјешће поред везира да наређује и распоређује, да гледа како се владају бегови и аге, а како раја, и да све јавља Бунапарти.” „То нит је било,нити може бити”, сузбијам ја влаха, „нико нама никад није у наше послове завиривао, па неће ни тај.” „Е, богами, ви гледајте како ћете”, каже мени он, „али конзула ће вам ваљати примити, јер што Бунапарта затражи_нико досад није одбио, па неће ни девлет у Стамболу. [...]"

Наравно да је на сличан начин могуће нијансирати и другачије текстове, а не само књижевне.

\section{ЛИТЕРАТУРА}

Анић/Силић 2001: Vladimir Anić, Josip Silić, Pravopis hrvatskoga jezika, Zagreb: Novi Liber.

Бабић и др. ${ }^{6} 2002$ [1996]: Stjepan Babić, Božidar Finka, Milan Moguš, Hrvatski pravopis, Zagreb: Školska knjiga, 2002. (6. izdanje).

Белић 1923: Александар Белић, Правопис српскохрватског књижевног јези$\kappa a$, Београд: Издавачка књижарница Геце Кона.

Белић 1934: Александар Белић, Правопис српскохрватског киижевног језика (Према прописима Министарства просвете), Београд: Издавачко и књижарско предузеће Геца Кон (треће, поправљено издање).

Белић 1950: Александар Белић, Правопис српскохрватског књижевног јези$\kappa a$ (ново, допуњено и исправљено издање), Београд: Просвета.

Боранић ${ }^{10} 1951$ [1921]: D. Boranić, Pravopis hrvatskoga ili srpskoga jezika, Zagreb: Školska knjiga.

Броз 1892: Ivan Broz, Hrvatski pravopis, Zagreb.

Бугарски 1996: Ranko Bugarski, „O jeziku i pisanju”, y: Lingvistika o čoveku, Sabrana dela, knj. 3, Beograd: Čigoja štampa - XX vek, 184-194.

Дешић 1994: Милорад Дешић, Правопис српског језика - Приручник за школе, Земун - Никшић: Нијанса - Унирекс.

Дешић 2015: Милорад Дешић, Правопис српског језика - школско издање, Београд: Klett.

Клајн 2000: Иван Клајн, „Конвенционално и суштинско у правопису”, [у књизи] Лингвистичке студије, Београд: Партенон, 2000.

Кликовац 2012: Душка Кликовац, „О интерпункцијском знаку три тачке (тротачки)". Научни састанак слависта у Вукове дане, 41/3, 2012, 63-92. 
Кликовац 2014: Душка Кликовац, „О двотачки”, Научни састанак слависта у Вукове дане, 43/3, 2014, 113-153.

Кликовац 2017: Душка Кликовац, „О знаковима у правопису (1): подела на реченичне и нереченичне и одговарајућа терминологија", Научни састанак слависта у Вукове дане, 46/3, 2017, 95-111.

Новаковић 1894: Стојан Новаковић, Српска граматика, Београд: Државна штампарија.

Ново правописно упутство [1943]: Ново правописно упутство српског књижевног језика, Београд: Министарство просвете.

Петровић 1912: Милан Петровић, Српска граматика с правописом, Нови Сад.

Петровић 1914: Милан Петровић, Српски правопис за средње школе, Нови Сад.

Пешикан и др. 1993: Митар Пешикан, Јован Јерковић, Мато Пижурица, Правопис српскога језика, Нови Сад: Матица српска.

Пижурица и др. 2010: Митар Пешикан, Јован Јерковић, Мато Пижурица, Правопис српскога језика, измењено и допуњено издање (Редакција: Мато Пижурица (главни редактор), Милорад Дешић, Бранислав Остојић, Живојин Станојчић), Нови Сад: Матица српска.

Правопис 1960: Правопис српскохрватскога књижевног језика, Нови Сад / Загреб: Матица српска / Матица хрватска.

Правописно упутство [1929]: Правописно упутство за све основне, средње и стручне школе, Београд: Државна штампарија Краљевине Југославије.

Симић и др. 1993: Радоје Симић, Живојин Станојчић, Бранислав Остојић, Божо Ћорић, Милош Ковачевић, Правопис српскога језика са речником, Београд - Никшић: ЧИП „Штампа”- ИТП „Унирекс”.

Симић и др. 1998: Правописни приручник српскога књижевног језика (приредила правописна комисија, одг. ред. Радоје Симић), Београд: Научно друштво за неговање и проучавање српског језика.

Симић 2003: Радоје Симић, Српски правопис, Београд: Јасен.

Стојановић 1891: Љубомир Стојановић, Лекиије из српскога језика за II разред гимназије.

Хрватски правопис 2013: Hrvatski pravopis, Zagreb: Institut za hrvatski jezik i jezikoslovlje (gl. ur. Željko Jozić).

Шипка 2000: Милан Шипка, „О српској правописној терминологији”, Јужнословенски филолог, LVI/3-4, 1411-1417.

Duška B. Klikovac

ON MARKS IN ORTHOGRAPHY (2): SENTENTIAL MARKS

Summary

Following the classification of orthographic marks presented in Klikovac 2017, this paper focuses on punctuation (=sentential) marks. First, it provides a global overview of the treatment of punctuation marks in the extant Serbian and Croatian orthography manuals, with the author's comments of 
their definitions and inventory, and then it proposes a distinction between the orthographic marks in the narrow sense, i.e. those that are written as separate signs, and the orthographic marks in the broad sense, i.e. those that are combined with text in different ways, including capital letters, font type and spaces. The concluding section presents arguments in favour of treating punctuation marks as a separate group in orthography manuals, and provides an illustration of how punctuation can contribute to achieving stylistic nuances in text. 